\title{
オートポイエーシス概念の建築的展開
}

\section{ARCHITECTURAL DEVELOPMENT OF CONCEPT-AUTOPOIESIS}

\author{
小島 孜* \\ Tsutomu KOJIMA
}

\begin{abstract}
By introduction of concept-Autopoiesis, I am trying to make better relationships between Architectural Design and planning theory. According to N. Ruhmann, human and human-society are classified 3 autopoietic systems, namely Body-system、Mind-system and Society-system.

This 3 systems corresponds to Architecture consisting of 5 parts, (1) Architecture as efficiency, (2) Architecture as functional-space, (3) Architecture as feeling-space (4) Architecture as information, (5) Architecture as system's structure. These 5 parts have the effectiveness for Architectural valuation.
\end{abstract}

Keywords : Autopoiesis, Body-system, Mind-system, Society-system, System's structure. オートポイエーシス、身体システム、意識システム、社会システム、システムの構造

1 はじめに

筆者は、論文「創造的合意形成に向けての方法論的考察」甘1〕お いて今田高俊氏の「メソドロジーの三角形」に示唆を受けて完成した 方法論モデル（図 1) を示し、その有効性を確認する作業の1つとし て、建筑計画系諸分野の、方法論モデルにそった定義づけを行い、各々 について、下記のような方法論的特性を明らかにしている。

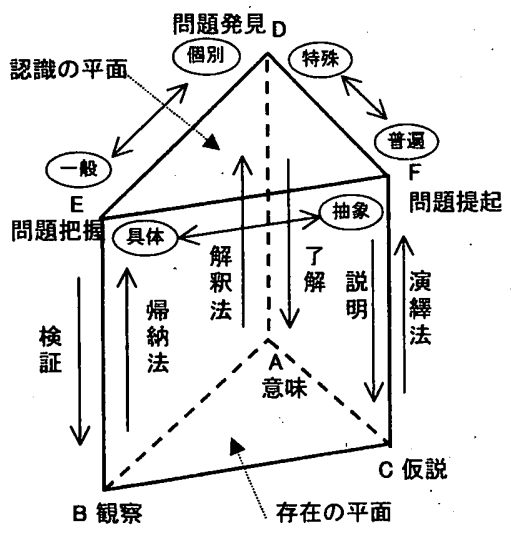

図 1 方法論モデル

設計 $[\mathrm{C} \rightarrow \mathrm{F} \rightarrow \mathrm{D} \rightarrow \mathrm{A}]$ 仮説演繹的な発想をもとに問題提起とし てのコンセプトをたて、それを特殊解としての設計提案に結びつける 行為。提案に対し、施主なり社会の了解が得られてはじめて、プロジ エクトは具体化する。

$\bigcirc$ 計画 $[\mathrm{B} \rightarrow \mathrm{E} \rightarrow \mathrm{F} \rightarrow \mathrm{C}]$ 観察帰納法的な調查研究により問題把握 を行い、それを抽象化することで理論としての問題提起をする行為。 現象を矛盾なく説明することで、理論としての有効性が評価される。 $\bigcirc$ 建築史 $[A \rightarrow D \rightarrow E \rightarrow B]$ 意味解釈的な分析・評価づけにより問
題発見を行い、ぞれを一般化することで歴史認識としての把握に至る 行為。時間をかけた検証によって、歴史認識の正統性が承認される。 $\bigcirc$ 建築論 $[\mathrm{A} \rightarrow \mathrm{D} \rightarrow \mathrm{F} \rightarrow \mathrm{C}]$ 意味解釈的な分析・評価づけにより 問題発見を行い、それを普遍化することで理論としての問題提起をす る行為。矛盾なく幅広い説明ができてはじめて、理論としての有効性 が評価される。

この論文で筆者は、方法論モデルの認識平面上での横スライド、す なわち、設計における「普遍」の特殊化、計画における「具体」の抽 象化、建築史における「個別」の一般化、建築論における「特殊」の 普遍化に着目し、分野横断的にそれらを活性化し、認識平面上を縦横 にスライドする、知的いとなみの重要性を強調している。

しかし方法論モデルの三角柱側面に着目すると、もう１つの興味あ る特色が見えてくる。それは、設計と建築論が同じ面上での逆方向の プロセスであること、そして両者が、お互いを逆照射しながら補完し あっていることである。つまり、建築作品は意味解釈的な建筑論によ って意味づけられ、建築論は仮説演繹的な設計コンセプトとの関係で、 有効性が計られているのである。

とするならば、計画と建築史の 2 つ側面上においても、それぞれ を逆照射する逆方向のプロセスがあるはずである。仮説からスタート し、そこから演繹的に導かれた抽象概念を一般化し、そこで得られた 知見を、具体のレベルにおとすことで検証していく、仮説演繹的な計 画学手法 $[\mathrm{C} \rightarrow \mathrm{F} \rightarrow \mathrm{E} \rightarrow \mathrm{B}]$ 、および、最新の建筑設計事例の観察に より把握された一般的傾向をもとに、個別の建築を意味づけしていく 現代史的な手法 $[\mathrm{B} \rightarrow \mathrm{E} \rightarrow \mathrm{D} \rightarrow \mathrm{A}]$ がそれである。

建築計画学と建築設計との、よりクリエーティブな関係を願ってい る筆者にとっては、計画側面上の逆プロセス $[\mathrm{C} \rightarrow \mathrm{F} \rightarrow \mathrm{E} \rightarrow \mathrm{B}]$ が特 に重要である。計画分野において主流をなす観察帰納的手法は、現状 の分析から普遍性を導き出すことを得意とし、設計の全体的質を底上 
げすることには奇与しているが、建築設計の創造的な部分にはあまり 貢献できていない。これに対し逆プロセスの、仮説をたててそれを検 証する演繹的な計画学手法は、抽象化の過程で、現状に縛られない飛 襍をすることができ、設計における創造を先導できる可能性を持って いる。

設計の創造的な部分にコミットできる、計画学の新しい展開を模索 する本論では、計画学的認識の根底にある機能概念について検討を加 え、そこから機能に代わりうる概念として「オートポイエーシス」を 抽出し、それを仮説として受け入れた場合の建築的展開を試行してい る。その可能性と意義を明らかにすることで、計画学の新しい展開の 方向性を示し、そこから建築の評価軸の見直しも併せ行いたい。

\section{2 人間の科学的把握}

建筑を、人間およびその集団との関連で科学的に考察しようとする とき、社会学および心理学との関係づけが必要となる。その要求は計 画学分野において特に顕著で、応用社会学、応用心理学といえる領域 が、計画学のなかで大きなウェートを占めている。

一方建築設計の分野でも、それを科学的に把握しようとすれば、社 会学や心理学との関係づけが必要となる。しかし現実には、社会学や 心理学の知見を引用的に使うことはあっても、本質的な部分での踏み 込んだ関連づけはほとんどなされていない。

この事実の背後には、人間という対象への、アプローチ方法の根本 的な違いがあり、それが計画学と建築設計の関俰を阻害する要因にな っている。

一般に社会学では社会の構成要素としての個人、心理学では刺激に 対して一定の反応をする個体としての個人、いずれも抽象化された客 体として人間が把握されている。計画学で扱う人間も同じく、抽象化 された客体としての人間である。抽象化、客体化こそが、人間を科学 的に扱うことを可能にしているのである。

これに対し建築設計では、ある建築を好きになったり嫌いになった りする、気まぐれではあるがビビッドな感性をもった、具体的で主体 的な人間との関俰が問題になる。つまり原理的に科学的であることを 拒否したところに、建築設計は成立しているのである。

その結果、建築設計を科学的に評価する基準が見失われ、個々人の 主観的な印象を前提にした、根拠の暧昧な評価がまかり通っている。 自閉した批評の世界で高い評価を得た建築作品が、人間と社会にとっ て、必ずしも良い結果をもたらしていないケースも、少なからず存在 している。

だからといって、計画学と建築設計のあいだに生じた断絶の責任を、 いまだ科学的になり得ていない、建築設計の側だけに帰すこともでき ない。計画学の歴史を振り返ってみると、建築設計の質を上げること を目指したはずの計画学が、科学的になればなるほど、建築設計から 遠ざかっていったことに気づかされる。

\section{3 機能概念の拡張}

とはいえ、建勧を人間と社会との関係で論じようとする時、異なる 個々人との関係をそのまま記述しただけでは、個別的データの膨大な 蓄積ができるだけである。それを活用していくためには、データを関 連づけて意味づけし、人間の能力で全体的把握ができるレベルにまで、 複雑性を縮减していく必要がある。
このような複雑性縮减の最も成功した方法は、多くの要素から成る 複雑な関係を、より全体的でシンプルな関係、それもできれば計測可 能な関係に写像することである。具体的な例でいえば、分子のランダ ムな運動の状態を「温度」として把握する方法や、大気の状態を「気 圧」として把握する方法である。社会学や建築計画学の分野でも、人 間および人間社会の複襍ないとなみを全体として把握し、「機能」に 写像する方法が大きな成果をあげている。

この機能概念の導入により、目標達成度と効率という必ずしも計測 可能ではないが客観性を持った尺度で、社会制度や建築を評価できる ようになり、その結果、社会や建築を科学的に捉えることが可能にな っている。その意義は建築分野で特に大きく、近代建築二機能主義建 築という図式が一般化し、「形態は機能に従う」とか「機能的なもの は美しい」といった、近代建築のテーゼが広く支持を得て、いまだに 大きな影響力を持っているのである。

しかし、科学的であることをめざす建築計画学と、非科学的な側面 を持つ建築設計とを、もっとスムースに接続しようとする時、目標達 成度と効率だけを重視し、人間のメンタルな側面を排除した、このよ うな機能概念で良しとする訳にはいかない。少なくとも目標達成に、 心理的な側面である喜びや感動も含め、またその「はたらき」にも、 効率と合理性だけでなく、楽しさや人間関係の豊かさを含めていく必 要がある。

このような拡張の試みは昭和 30 年代から行われており、注2)建築計 画学の分野ではすでに一定の成果をおさめている。しかし建築設計の 側から計画学を見ている私にとっては、いまだ未解決の基本的な問題 が残っているように思える。その1つは、目標の達成度評価において 「喜びや感動、満足度」と「品質や性能」という次元の違う指標をど う相対化するのか、その「過程での楽しさや人間関係の豊かさ」を、 「効率」とどう関係づけるのかという問題である。

もう1つ、目標そのものをどのように設定するのかという問題も重 要である。優れた設計では、与えられた機能を充足するだけでは満足 せず、別の付加価値を加えるべく努力をしているのだが、近年諸施設 の複合化が進むなか、さらに高度化し、新しい用途の発生や機能の創 発をテーマにするケースが増えている。

このような、創発的に機能を生み出していく建築のあり方は、建築 設計での最もホットなテーマの 1 つであるが、機能概念を拡張するだ けでは、この自己言及的なテーマに応えていくことができない。

このように、機能概念を拡張するだけでは解決できない問題が増え、 かつ重要度を增している。建築設計と計画学のさらなる向上を実現す るためには、機能に代わる、あるいは機能を補完する新しい方法、複 雑性縮減の手段を模索していかなくてはならない。

\section{4 システム理論の導入}

建築設計と計画学をとりまく、このような課題に応えるため、機能 概念のシステム論的再構成に取り組んでいきたい。

建築におうるる機能は、「建築物が用途のために果たすべき役割」と して理解されているが、もともと機能は、生物の贜器や諸器官の働き を表わすために定義された概念で、「部分の固有のはたらきが構成さ れ、統一された全体としてのはだらきが生み出されている状態での部 分の役割」を意味していた。つまり機能概念には、システム論的な視 点が含まれていたのである。 
また複雑な対象を、属性をできるだけ失わないで単純化する方法と して、「㝍像」以外に、関係性そのものの「プログラム化」が考えら れる。プログラム化は、複雑な対象を相互に関係した 1 つの系=シス テムとして理解し、モデュール化、すなわち機能的まとまり毎に部分 を切り取り、それを閉鎖系として捉えることで、部分の内的諸関係を 潜在化し、全体の複雑性を縮減している。

しかし今までのシステム的手法では、部分を全体に関連づける時、 全体としての目指すべき目的に対し、いかに効率良く部分を組織する かという、制御の論理にもとづいてプログラム化されていた。このよ うなシステムは、当然機能概念とも相性が良く、ハーバーマスがネガ ティブな意味で指摘するように、注3) 機能概念のもつ合目的的、効率 優先的な性格を、否応なしに補強していたのである。

このようなシステムを変革する方法として、最初に考えられるのは 効率優先の機能システムに、心理的な側面に配慮したバイパス回路を 補足することである。しかしこのような方法では、モデュール化によ る複雑性の縮减が少なくなり、システム概念導入のメリットが曖昧に なるうえ、先の機能概念の扡張時と同じ問題、目標の達成度において 「喜びや感動、满足度」といった指標を、「品質や性能」といった目 標と並べてどう評価するのか、その「過程での楽しさや人間関係の豊 かさ」を、効率との関倸でどう評価するのかという問題が、未解決な ままで残ってしまう。

もう 1 つの方法は、フィードバック回路を補足する方法である。フ イードバック回路に主眼をおいて、機械的モデルと生物的モデルとを 橋渡しする概念として、サイバネティックスがあるが、この理論は、 工学と生物学のシステム研究を関連づけ、新しい制御概念や人工知能 の研究と併せ、自己安定性、自己組織化、成長、進化などのテーマを も扱っており、私達と共通する目標をもっている。

しかし、その主眼は生物的システムの工学的利用にあり、あくまで 生命を客体として把握しようとしている点、効率的な機能充足を主目 的にしている点では、従来のシステム理論と変わらない。生命が持つ ビビッドな本質に迫るためには、システム全体を客体としてみる外部 的視点から、内部から生命を捉える内部的視点へと変換し、システム の目的を、効率的機能充足から、システム自体の調和と活力、成長と いった、自己充足的なものに転換していく必要がある。

\section{5 オートポイエージス概念の導入}

生命を内部的視点加ら把握し、自己安定性、自己組織化、成長、 進化といった性質を直接的に扱う概念として、オートポイエーシス がある。オートポイエーシスとは、チリの神経生理学者、マトゥラ 一ナとヴァレラが、生命の本質は、自己の要素を自己準拠的に再生 産している点だとして、その特性を記述するために用いた造語で、 自己産出というょうな意味合いであるが、ドイツの社会学者ルーマ ンはそれを意味システムに広張し、人間の意識活動もコミュニケー シィン活動も、生命システムと同じ自己準拠的閉鎖システム、つま りオートポイェーシスであるとしている。

一般にシステムは、「部分の総和以上のものである統一体」と定義 され、要素の集合として理解されているが、ルーマンは要素間の諸 関係の集合と捉え直すことで、部分の自己準拠性を確保して、シス テム概念とオートポイエーシス概念を接続し、システムの構成要素 を非物質的なもの、意識やコミュニケーションに抗張している。
このオートポイエーシス概念のルーマン的解釈によって、人間の 身体的活動と意識の活動、および集団的な社会的活動を、総括的に 理論化する道が拓かれる。

ルーマン自身は、自らのオートポイエーシス概念を厳密には定義 していない。しかし多岐にわたる論文や著作のなかで、次々と多様 な概念を演繹的に導きだしている。それがあまりに多様なため、筆 者のような部外者にとっては、何が定理に相当する原則なのか解り づらくなっており、全体としての体系的把握が困難になっている。

ルーマン理論の体系化は、今後ルーマン研究者の手で進められて いくだろうが、それを待てないこの論文では、末尾に参考図書とし て示したルーマンの著作の一部とルーマン理論の解説書から、筆者 なりに理解しつつ整理してきた、今後の建築的展開に関連する原則 を列記し、次につなげていきたい。

原則 1 オートポイエーシス・システムとは、もろもろの構成要 素が一つの循環過程のなかで相互に作用しあって、その際にシステ ムの維持に必要な構成要素が、不断に産み出されている閉鎖系であ る。注4)開放系であるとされてきた有機的システムは、エネルギー と情報に関して開かれているとしても、要素の産出に関しては閉鎖 した自己準拠的システムである。

原則 2 システムの構成と要素の構成は同時構成的である。あら かじめ要素があってそれらが関倸づけられるのではなく、逆に何ら かの関係が前提されて要素が産出されていく訳でもない。その両者 が同時構成された時に、システムも同時的に構成される。

原則 3 オートポイエーシスの作動を通じて産出された要素が、 システムのオペレーションを継続しつつ、要素間で安定した関係を 成している時、要素間の接続可能性を制限している仕組みをシステ ムの構造という。構造はシステムのオートポイエーシスが、特定の 要素による特定の関係によって継続されるよう「はたらき」を規制 するが、前もって存在している訳ではなく、諸要素の接続可能性が 制限されることによって、結果として形づく.られたものにすぎない。 構造とは、関係を限定してはいるが変化が可能なものである。

原則 4 環境と異なるものとしてのシステム゙は、複雑性の縮減によ って成立している。差異のあるところには必ず複雑性の縮減があり、 一定の差異に基づいて複雑性の縮堿を成しうるものがシステムであ る。複雑性が縮減されなければ、世界は未規定性そのものであり、複 雑性の縮堿によりシステムは環境から分離され有意味な存在となる。 従ってシステムの複雑性は環境のそれよりも小さい。

原則 5 システムのオペレーションは、ある期間は意味をもって存 続するが、そのままでは必ず堿衰し消减する。オペレーションを継続 するためには要素の再生産が必要であるが、閉鎖系であるオートポイ エーシスでは、要素を環境から調達することはできないから、システ ム/環境間の差異としてのエネルギーや情報を絶えず導入し続け、要 素を自己継続的に再生産していく必要がある。

\section{6 心的システムと社会システム}

オートポイエーシス概念を意味システムに拡張するに際しルー マンは、「オートポイエーシス・システムは生命システムと意味シ ステムに分けられ、意味システムはさらに、心的システムと社会シ ステムに分けられる」としながらも、その厳密な定義づけを行って いない。注5) ルーマンに依拠しつつ筆者なりの定義づけを行い、心 
的システムと社会システムに関する原則を加えていきたい。

《心的システムの定義》 個々人の意識活動・心的システムは、 感覚器官を通してインプットされた情報を、一旦ばらばらな断片に 分解した後、自らの知識や経験、記憶、価值観にもとづいて再構成 することで意味づけし、その意味づけされたものにもとづいて、次 の情報をまた同じように処理する閉鎖的な系である。

《社会システムの定義》 社会システムは、そこでの目的、利害 や価値観、人間関係などに一定の支配を受けながら、人と人とのコ ュニケーションが欣のコミュニケーションを引き出す活動を継続し、 構成メンバーや役割が変わっても、外部に対し何らかの差異を持ち続 けている閉鎖的な系である。

原則 6 複数の主体による意識活動のネットワークである社会 システムは、各主体の意識活動である心的システムより複雑である が、独立した自己準拠的システムであり、各人の心的システムにと っては、外部を成す環境である。同時に社会システムにとっては、 各人の心的システムもまた環境である。

原則 7 コミュニケーションは、複数の心的システム間における、 三層の選択過程の結合によって成立する。注6) 送り手がまず情報を 選択し、それを特定の手段を選んで伝え、受け手が様々に解釈し理 解するというコミュニケーションの過程には、その各々の段階で、 別の選択をした可能性(コンティンジェンシー)が含まれている。コ ミュニケーションとは、常に誤解や曲解の可能性のある、一義的で ないが故に創発敵な関係なのである。

原則 8 社会システムも必要に応じてシステムの構造を変え、諸 要件を変化させることで柔軟に対処し得る、可変的なシステムであ る。しかし複雑なシステムは構造なしには存続できないし、存続し 続けることで、否応無しに構造を発展させている。つまり、可変的 ではあるが保守化する必然的傾向を持っている。

\section{7 オートポイエーシス・システムと建築}

以上の原則は全てルーマンが示唆していたもので、筆者のオリジナ ルな見解ではない。しかし先の定義で述べたように、筆者の心的シ ステムは、ルーマン由来の情報を一旦ばらばらな断片に分解した後、 自らの知識や経験、記憶、価値観にもとづいて処理することで意味 づけし、その意味づけされたものにもとづいて次の情報を処理し、 結果として、このような見解に到達している。

またルーマンは、自らの理論を「機能一構造的システム理論」と 称し、機能主義者を自認していたが、そのルーマンを今田高俊氏は、

「構造をも機能で説明しようとする、機能ラディカルリズムを表明 する近代主義の権化だ」として批判している。注7)

こうした見方に対し、ルーマンを建築の立場で読み直し、機能に 代わり得る概念として、オートポイエーシスを位置づけようとする 筆者の見解は、独自のものである。これまでの検討で、オートポイ エーシス概念を建築に導入し、機能に代わる概念として活用できる 見通しと、その意義が明らかになったと考えたい。

すなわち、オートポイエーシス概念のルーマン的解釈により、人間 と社会を内部的視点で捉え、システムの目的を、調和と活力、成長と いった自己充足的なものに転換することができる。

また具体的欲求をもった主体的人間像と、社会を構成する客体的人 間像との、立脚点の相違にもとづく対立を解消し、さらに、意識活動
における感動やアイディアの創発といったテーマを、客観的に扱うこ とが可能になっている。

しかし建築にとってより重要なことは、人間とその社会を、生命シ ステム、心的システム、社会システムの 3 種類の独立した閉鎖系に分 け、単純化して考察する道を拓いたことである。ここでの建築は、人 間と社会にとって外部を成す摆境であるが、3種類のオートポイエー シスが各々独立した閉鎖系であるため、人間および社会と建築との錯 綜した関係を、身体 (生命システム)、意識 (心的システム)、コミュ ニケーション関係（社会システム）との、個別的な対応関係に分けて 検討することが可能になっているのである。

まず意識と切り離された身体 (生命システム)にとっての建築を考 えると、身体そのものに対しては、命の安定的自己継続を保証する「性 能としての建築」が対応し、身体的行為に対しては、活動のために必 要な場を提供する、「機能空間としての建築」が対応する。

意識 (心的システム) との関係では、感覚や感情といった本能に近 い意識領域には「体感空間としての建築」が対応し、理性的な意識活 動に対しては「情報としての建築」が対応する。

ここでは空間を機能空間と体感空間に分けて把握している。従来は この両者を分けずに理解しようとしていたため、機能概念を人間のメ シタルな側面に拡張する必要が生じていたが、身体と意識が独立した 別の閉鎖システムであることから、身体との関係で論ずべき機能空間 と、感覚や感情といった意識活動との関係で論ずべき体感空間とを、 厳密に区別する必要が生じてきたのである。

最後の、個々人の身体とも意識とも切り離された、複数の人間によ るコミュニケーション関倸（社会システム）に対しては、「システム の構造としての建築」が対応する。システムの構造として建築を把握 することは、今までほとんど行われてこなかったが、社会システムに おける建築は、習慣や社会ルールなどと共に、人間相互の関係性を制 限し方向づけることで、システムを安定化する役割を担っており、シ ステムの構造としての条件を備えている。

以上結論を先に示したが、生命システム、心的システム、社会シス テムと、各々に対応する建築の関係をまとめると図 2 になる。

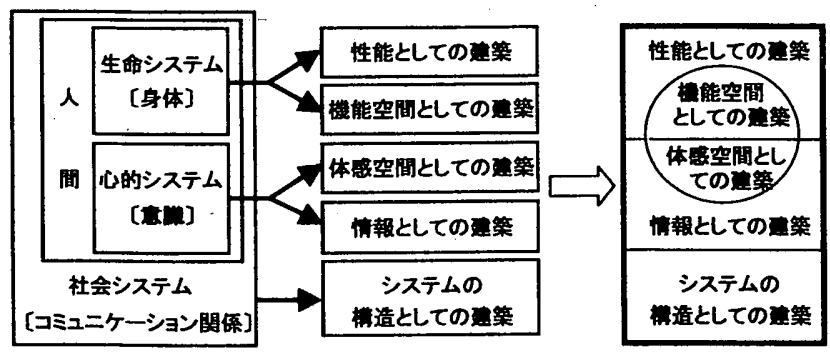

図 2 人間および社会と建築の関係

この結論は、機能主義を乗り越えるための新しい方向を示唆してい る。それは、人間と社会の関係をシステムとして、それも内部的視点 から見たオートポイエーシス・システムとして把握し、閉鎖系である 人間の身体と意識、およびコミュニケーション関係に対応する、別々

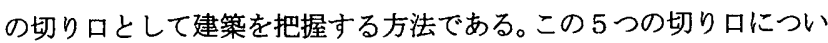
て個別に吟味し、内的視点への転換によって、どのような可能性がひ らけるのか検討していきたい。 


\section{8 性能としての建筑}

命ある身体そのものに対して梳、命の安定的自己継続を保証する 「モノ」としての性質、性能だけが関係し、それ以外の建築的な質は 無関係である。この建筑的性能は、科学的に検証することが可能な物 理的な安全性、および生理的な煡康性と快適性に還元して語ることが できる。これらの指標は、建築を構成する各部位の性能にも還元でき、 これら部分性能の集合で「性能としての建筑」の総合評価にあてるこ とができる。要素還元主義的方法がまだまだ有効性を持ち、建築の工 学的知見がそのまま有効性を持ち続ける。

、しかしこれはあくまで、命の自己継続が安定的に成立している場合 のことで、身体の安全が危険にさらされるような極限的状況では、あ る部分の性能的破綻を他の部分がカバーする、より有機的な対応が要 求され、そこでは全体の性能を「部分性能の関係性の集合」として捉 え直す、内部的な視点が不可欠となる。生8)

そこでの計画学は、「性能としての建築」を成立させるための技術 的条件と社会的条件の調整、具体的には、性能と経済性の調整や安全 性と健康性・快適性の調整などのテーマを扱うことになるが、異なる 性能調整にあたっては「部分性能の関倸性の集合」として全体性能を 把握する、淮オートポイエーシス的な視点が必要となる。

建築設計に関しては、異なる性能を持つ部位や部品をどう接続し、 総合的な性能をどう保証するのかという、システム設計とディテール 設計が主要テーマになるが、ここでも設計が高度化すればする程、性 能の相互補完性が強まり、「部分性能の関倸性の集合」としての工学 的な知見と、計画学的知見にもとづく部分性能の相互関係の調整が重 要になる。

\section{9 機能空間としての建築}

身体的行為のために必要な場を提供する「機能空間としての建築」 には、空間の物理的側面が関係する。身体にとっては、活動にふざわ しいスペースが確保されておればよい訳で、その質的な評価は、広さ や高さや幅といった身体スケールに対応した空間スケールと、そこで 行われる行為に対応した機能性の両面ではかられる。 ここでいう空間スケールは、意識（心的システム）に関連して生ず る質、奥行感や広がり感、上昇感といった感覚的なものを除いた、純 料に物理的なスケールで、もちろん科学的に計測することが可能であ り、人間工学的な研究は普遍的有效性を持っている。

そして身体との対応で機能をみる限り、人閒のメンタルな側面も社 会的な側面も非除して考えることができる。その結果機能概念を無理 に拡張する必要はなくなり、今までの計画学的知見を、そのままで活 用することができる。

しかしここで、「機能の創発」に着目すると、機能的関係が変化す ることで新しい用途が発生したり、用途の変化が同じ空間の機能を変 化させていることに気づかされる。原則 2 に準じてトシステムとして の用途と要素としての機能の構成は同時構成的である」と考え、さら に原則 $3 ， 4 ， 5$ を淮用し、内部的視点一と変換することで、「機能 の創発」という設計分野での今日的テーマに、建築計画学がコミット できるようになる。

\section{0 体感空間としての建築}

機能空間においても、私たちの感性は否応なしに空間を感じ取り、 身体とは別の内的オペレーションを作動させている。そのような建築 架間の側面を「体感空間としての建築」として把握し、従来の機能の 㹡張ではなく、心的システムとの関係から吟味していきたい。

空間とは「モノ」で構成された隙間、ボイドであるが、この「モノ」 の構成を空間として認識する能力は、人間以外の動物にも認められる もので、動物垟は独自の空間認識能力を磨くことで、きびしい生存競 争を生き抜いている。ここでの空間認識怯、感覚器官によって捉えら れた「モノ」の属性に関する断片的情報を、本能にもとづいて再構成 することで生じている。

人間の場合も基本は同じであるが、本能だけで空間を認識している 訳ではない。人間の脳は、身体と脳の橋渡しをしている脳幹（爬虫類 腷）と、情動を生み出す太脳辺縁系（哺乳類腷）の上に、人間独自の 脳・大脳新皮質が重なった三層構造をしているが、人間の空間認識に は、動物由来の䋃幹と大脳边縁系だけでなく、人間的な意識活動を担 う大脳新皮質が関与しているのである。

大脳新皮質のなかで、生後最も早く活動を開始するのが空間を認知 する頒域で、おかげで赤ちゃんはいち早く直感的に空間を認識できる ようになる。赤ちゃんが「いないいないばあ」を好きなのは、相手が 本当に消えたのではないことを、理解しているからなのである。注9

また人間の視覚は学習することでさらに高度化し、例えば平面的な ものであっても、立体とみなした方が合理的な場合には、学習するこ とで脳のネットワークを修正し、立体として理解するようになってい く。生 10)

このように人間の空間認識は、本能や無意識的な意識活動と深い関 倸を持つと同時に、いち早く認識のベースを整え、経験を重ねること で高度化した複雑な意識活動なのである。この空間認識のメカニズム については、まだまだ解明されていないことも多く、脳生理学や認知 科学の知識だけでは「体感空間としての建策」に迫ることはできない。 ここではその最新の成果を参照しつつも、「的システム」のルーマ ン的解棌にもとづき、論を進めていきたい。

空間とは本来「モノ」で構成されたボイド、すなわち実体なき存在 であるが、実体がないのに存在として認識されているのは、建築空間 を構成する実体的要素そのものではなく、実体ではない「要素間の関 倸性」が認識された結果であると考えてみたい。

事実、私達が視覚的に空間を認識するとき、それ自体は空虚である 空間を、例えば床と壁、壁と壁、壁と天井の各輪郭線の集合、つまり は構成要素間の関係性の集合として理解している。また空間の奥行は、 重なり合っている要素間の関係性、手前にある要素によって隠された 部分の存在によって認識されている。

このような関係性の認識は、伈的システム」のオートポイエーシ ス的営みそのものであり、個々人の知識や価值観、経験や記憶、そし て無意識との関倸によって生じている。視覚以外の体感が空間的イメ ージを㬇起する場合も同じである。

このような認識は、空間体験を伴わない場合でも可能で、私達は心 的システムの中だけで架間要素を関係づけ、空間イメージをつくりだ すことができる。また、空間構成要素が直接心的システムに働きかけ、 偶発的に過去の記憶や無意識と関保を持つことがあり、その時、感動 を含む様々な情動が生み出されている。こう考えることで、人により、 また時により異なる、一義的でない体験として「体感空間としての建 


\section{築」が把握される。}

この偶発性を取り込んだ新しい視点を受け入れることで、計画学は 新しい展開の方向を獲得し、建築設計に新たな貢献をすることができ る。それは、空間構成要素の関係として空間を把握し、それと体感と の一義的でない相互関倸についてのデータを蓄積し、それを整理する ことである。この作業は、建築構成要素のデザイン的意味を研究した 労作、アレキサンダーの「パターン・ランゲージ」を、関係性の視点 で読み直すことにもつながり、アレキサンダーの孤立した個人的業績 を、計画学と建築設計に、再接続することになるはずである。

\section{1 情報としての建築}

原則 5 で述べたように、完全な閉鎖系である意識にとって、外部の 環境要素は、エネルギーもしくは情報としてしかシステムと関俰する ことができない。エネルギーになり得ない建築は、意識にとって情報 以外の役割を担うことはあり得ない。

この「情報としての建築」にとっては、実際に体感された建築も、 写真や映像、図面や模型、ドローイングで表現された建築も、情報と いう意味では等価である。こうした情報は、脳の中でのオートポイエ ーシス的いとなみによって理解されており、平面的なものを立体的に 理解する能力を持った人間にとっては、原則 7 の情報が発信される段 階においても、伝達される段階、理解される段階においても、体験さ れた建築の直接的情報が、メディアを介した間接的情報に比べ、価值 が高いということはないのである。

このことは、写真では感じとっていた空間感覚を、実際に体験した ときには感じなかったり、空閒そのものよりもドローイングに感動し たり、実際の経験でしばしば実感しているところである。

異なるのは、体感された建築では視覚以外の德覚や触覚情報の影響 が少なくないが、メディアを介した情報ではほぼ視覚だけに、それも メディアによってセレクトされ加工された、視覚情報に限定されてい ることだけである。

しかしこの違いが大きな問題を提起する。「情報としての建築」の 価值は、情報の受け手である個々人の心的システムが、どれだけ活性 化したかによって計られることになるが、その結果、受け手が持つ情 報との差異の大きさだけが一人歩きをし、メディアによる情報の操作 や誇張をもたらしてしまうのである。

しかしこのことをもって、建勧の情報としての側面を、間違った価 値軸だとして排除するのは適切でない。情報化が進み、すべての分野 でメディア化が進行している現在、操作が可能な「情報としての建築」 の価値を、建築の新しい属性として積極的に受け入れていく必要があ る。

ただし「情報としての建築」の価値が、建築にとっての価値なのか、 それとも、情報メディアにとっての価值なのかを、慎重に見極めてい く必要がある。情報の操作や誇張、それ自体を否定する必要はないが、 受け手の心的システムの活性化を、一過性の瞬間的な差異だけで判断 するのであれば、それは情報メディアにとっての価值にすぎないこと になる。

「情報としての建築」における建築の価値は、受け手の心的システ ムにおいて、知識や価值観、経験や記憶、無意識と反応して、新たな 差異や情報を、継続的に自己再生産できていることにある。情報の操 作や誇張の有無よりも、受け手の心的システムが活性化した回数と、
その活性化の樑さと持続時間が重要なのである。

それでは、心的システムの活性化が持続し、記憶に残り、新しい情 報と共振して再活性化するためには、どのような条件が必要なのだろ うか。差異の大きさも条件の 1 つであるが、記憶に残るためには、そ れまでに記憶されていた情報と関係づけられ、意味づけされることが 必要である。またそれが再活性化するためには、もとの情報が意味づ けの素材として再使用されることが重要で、そのためには単に目新し いだけでなく、建築の普遍的なテーマに対して、何らかの問題提起を するものでなくてはならない。

このような、意味づけに重点を置いた「情報としての建築」の把握 は、情報としての鮮度と目新しさだけが一人歩きする状況に歯止めを かけ、建築の総合的な評価に新しい側面を加えることになる。情報の 鮮度だけを追求しがちな建築設計に対し、計画学は、新たな差異や情 報を自己再生産している事例の収集と、意識活動との相関を明らかに することで「情報としての建築」に貢献できるし、すべきなのではな いだろうか。

\section{2 システムの構造としての建築}

コミュニケーション関係においては、話し手と聞き手による解釈の ズレが、次のコミュニケーションを生起する原動力になっている。し かしズレが大きすぎると、当然ながらコミュニケーションは成立しな くなり、単なる人の集合になってしまう。

このような事態を回避する役割を担うのが、要素間の接続可能性を 制限し、方向ゔけすることで安定化するシステムの構造である。建築 も、同じ空間体験を強いると同時に、人々の行為を制限する役割を担 っており、まさしくシステムの構造として機能している。

例えば何の変哲もない四角い部屋であっても、そこに室名をつける だけで、建築は人を選び、そこでの人間関倸を方向づけることができ る。このことは、「システムの構造としての建築」という切り口が、 特別な建築のみに通用するものではなく、全ての建築に関係している ことを示している。

しかし現代社会では、安定と同時に自由を求める傾向が強く、「シ ステムの構造」が露骨に見えてしまうことが嫌われ、ルールや規則よ りは、建築のような、曖昧に支配力を行使する「構造」が求められて いる。言い換えれば、「システムの構造」としての支配力を隠蔽する デザインが、建築に対して要請されているのである。

自由のもう 1 つ側面は、多くの可能性から選択できることであり、 新たな可能性を生み出せることである。建築設計の最先端では、「シ ステムの構造」を隠蔽するという要請に応えるだけでは満足せず、も っと積極的に、安定を保持しながらどこまで自由を許容できるのかを 見定め、可能なかぎり自由度の高い空間・建築を赛現していこうとし ている。

その結果、利用目的のはっきりした目的的な空間よりも、ロビーや ラウンジ、ギャラリーといった、つなぎの役割を担う媒体的な空間に カが注がれるようになり、そこで偶発的なコミュニケーションを生み 出す心゙く、さまざまな試みが行われている。

さらに最近では、目的的な空間においても、部屋の輪郭を曖昧にし て機能の重なりを仕掛けることで、新たな機能の発生を促そうとした 事例が登場している。仙台メディアテークがその代表例であるが、こ こでは、吹き抜けを内蔵するチューブ状の柱が場所の固有性を生み出 
し、巧みにデザインされた家具の配置と相俟って、1つの空間のなか で複数の機能が自立性を保ちつつ重なり合っている。そこでは複数の グループ、すなわち、複数の社会システムが無理なく同居し、相互干 涉によって、偶発的な新しい関係性が生まれている。こうした状況は、 まさに創発的に機能が生まれている状況であり、こうした創発的機能 生成の成功事例を「システムの構造」として読み解く作業は、計画学 の新しいテーマとしての意義を持っている。

しかしその行き過ぎは、混乱につながる危険性を持っている。どこ までの自由を許容できるかを決めるのは、建築ではなく、あくまで社 会システムの側である。例えば学校建築において、教室配置をオープ ンにした事例が増加しているが、それが、学校という制度の成熟に伴 う新しい方向であるとしても、個々の事例における是非については、 社会システムの構造との関係で論じられねばならない

もう1つ検討すべきは、情報化と建築の関係である。「情報として の建築」にとつて、建築のI T化は情報の質を高めはするが、その本 質を変えるものではなかった。それに対し「システムの構造としての 建築」に対しては、本質的なレベルでの影響が認められる。それは情 報化が、システムの構造としての支配力を隠蔽する、画期的な技術を 提供できることにある。その結果情報化社会では、建築の役割が徐々 に後退していくことが愳念される。こうしたなか、システムの構造と しての支配力を鿵蔽する役割から開放された建築は、もっと積極的に、 機能の創発を仕措ける役割を担っていかなくてはならない。

\section{3 まとめ}

以上本論文では、生物学に起源を持つオートポイエーシス概念を社 会学分野に拡張したルーマン理論を、建築分野に拡張することを目指 し、その可能性と意義について検討してきた。その結果、目標達成度 と効率という価值軸に縛られ、脱近代に向けた諸要求に応えきれてい ない機能概念に代わり、人間と社会と建築との諸関倸をシステムとし て、それも内側の視点からみたシステムとして把握する、オートポイ エーシス的な展開の有効性を確認することができた。

次に、人間と社会の全体をカバーすると考えられる 3 つの閉鎖シス テム「生命システム、心的システム、社会システム」に対応し、「性 能としての建築、機能空間としての建築、体感空間としての建築、情 報としての建築、システムの構造としての建築」という、.5つの切り 口を対応させ、その各々について、従来の外部的な視点による把握と の違いについて検討を行った。

その結果建築についても「要素の集合」としてではなく、「要素間 の諸関係の集合」と考えることで、関係性が不安定化すると同時に新 たな生成が期待される、極限的な状況や創発的な場面にまで、考察の 射程を延ばしていける見通しを得ることができた。そうなれば、従来 の研究成果を活用しながら、建築計画学は設計の創造的な部分に貢献 していくことができる。

これらの切り口は、建築設計を評価するときの評価軸としても有効 である。設計に对する評価には、どうしても怨意的にならざるを得な い側面があり、評価を一義的に決定できないところにこそ、デザイン の魅力がある。しかし、少なくとも多様な評価を相対化する評価軸に ついては、何らかの整理をしていく必要がある。

この $5 つ の$ 切り口は、「性能としての建築」、「機能空間としての建 築」にウェートをかけ過ぎていた計画学的な評価と、建前上は「体感
空間としての建築」にウェートを置きつつ、本音としては「情報とし ての建筮」にシフトし、「性能としての建築」と「機能空間としての 建築」を軽視していた設計側の評価とを、共通の土俵で相対化するこ とができ、両者の関係を修復し活性化していく上でも、重要な意義を 有している。

機能概念を超克するという大命題を掲げた本論文は、まだそのアウ トラインを示しえただけである。また仮説演繹的な論理構造を標榜し ながら、十分な検証ができているとは言えない段階にある。自然科学 と異なり、再現可能な実験による検証ができない社会科学では、仮説 の検証は多くのケース・スタディーによるしかないが、この論文をき っかけに、できるだけ多くの方々の関心を得て、ケース・スタディー による検証を多面的に進めていければと願っている。

注

\#11 日本建築学会計画系論文集 第524号 p327〜332 1999 年 10 月

注2)例えば、足立孝は昭和 31 年 9 月の日本建築学会論文報告集 54 号に、論文 「機能拡張としての心理学的研究」を発表している

注3)機能主義を批判する立場から社会二層構造論を展開したハーバーマスは、 能優先の合目的的、効率的行為を特徵づける概念としてシステムをあげ、 それと拮抗関係をなすべきコミュニケーション的行為を特徵づける補完 概念として、生活世界を提示している

注4）筆者が理解し簡略化した定義である。例えばマトウラーナとヴァレラは、著書 「オートポイエーシス」の71頁において、「オートポイエーシス・システムとは、 構成素が構成素を産出するという産出過程のネットワークとして、有機的に構 成されたシステムである。このとき構成素は、(1)変換と相互作用をつうじて、 自を産出するプロセスもネットワークを、絶えず再生産し実現する。(2)ネットワ 一クを空間に具体的単位体として構成し、またその空間において構成素は、 ネットワークが実現する位相的領域を特定することによってみずからが存在す ると定義しているが、ルーマンはその(2)の部分をカットして理論を展開して いるようである

生ら「自己言及性」9頁においてルーマンは、意味と生命とを異なった種類のオー トポイエーテイックな組織としてきっちりと区別することが導かれ、また意味を使 用するシステムは、意味に基礎づけられた再生産の様式として意䇅を用いる か、あるいはコミュニケーションを用いるか同かということに応じてふたたび区 別されなければならないりとしているが、その根拠は示されていない

(46) オリジナル論文についての言及はないが、ケニールとナセヒは「ルーマン社会 システム理論」96頁において、「コミュニケーションは情報の選択、多数の伝 達可能性からの選択、多数の理解可能性からの選択が、適切に行われた場 合に成立する。三つの選択のはたらきのすべてが総合されるときにはじめてコ ミュニケーションというものが成り立つ」として、ルーマンの考えを紹介している

(27) 意味の文明序説 今田高俊 東京大学出版会、 $081 \sim 82 \quad 2001$ 年

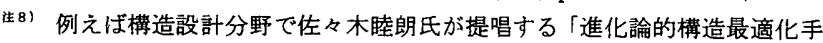
法」は、その先駆的事例だといえる

491脳と心の地形図 リタカーター 原書房、p34 1999年

洁 10 ) その具体的実例は、ドナルド ホフマン著の視覚の文法（紀伊国屋書店 2003 年) に詳しく記載されている

参考文献

ニクラスルーマン：自己言及姓こつい、国社 1996 年

ニクラス ルーマン：ルーマン、学問上自身安語る、神泉社 1996 年

ニクラス ルーマン：近代観察 法政大学出版局、2003年

クニール十七ヒ：ルーマ社会ンステム理侖、神泉社 1995 年

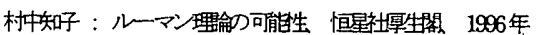

中同成文：“現代思想の冒険者たち・ハーバーマス 講的社 1996 年

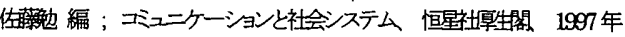

マトウラーナ、ヴァレラ：オートポイエーシス 国文社 1982 年

河本英夫：オートポイエーシス2001、新嚄士 2000年

馬場请雄：ルーマンの社会理侖 勁草害客 2001 年

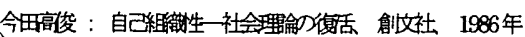

